\title{
The effects of entrepreneurial long-term commitment on post-IPO performance: Chinese evidence
}

\author{
Dongmin Kong ${ }^{1}$, Maobin Wang ${ }^{2^{*}}$ and Xiyu Zhang ${ }^{3}$
}

\author{
* Correspondence: wangmaobin@ \\ uibe.edu.cn \\ ${ }^{2}$ School of Banking and Finance, \\ University of International Business \\ and Economics, 10 Huixindong \\ Street, Chaoyang District, Beijing \\ 100029, China \\ Full list of author information is \\ available at the end of the article
}

\begin{abstract}
Long-term commitment is a motivational factor that drives people towards entrepreneurship. Scholars and practitioners have lacked a robust and validated instrument for measuring long-term commitment and its dimensions in the specific context of entrepreneurship. Based on a unique dataset of emigration statuses of Chinese entrepreneurs, we develop an instrument of entrepreneurial long-term commitment and test its impacts on corporate outcomes and entrepreneurs' individual behaviors. We observe that entrepreneurial long-term commitment significantly affects corporate policies, long-term shareholder wealth and entrepreneurs' individual behaviors. Our research also helps to evaluate the values of these entrepreneurs in China.
\end{abstract}

Keywords: Entrepreneur, Long-term commitment, IPO underperformance, Foreign residency rights, China

"In a bacon-and-egg breakfast, the chicken is involved, but the pig is committed."

-An old joke

\section{Introduction}

According to the Cambridge English Dictionary, commitment is "a willingness to give your time and energy to something you believe in, or a promise or firm decision to do something.". Long-term commitment is at the heart of entrepreneurship, because it can fuel entrepreneurs with an unshakable sense of purpose, keeping them going during days when everyone else tells them to quit. Accordingly, scholars have pressed for a deeper understanding of long-term commitment as a central element of entrepreneurial personality traits (Meyer and Allen 1991; Meyer and Herscovitch 2001; Duckworth et al. 2007; Duckworth et al. 2011).

In spite of the importance of understanding the nature, causes and effects of entrepreneurial long-term commitment, there is a dearth of systematic empirical evidence for the role of long-term commitment in entrepreneurship. At the heart of this problem, scholars and practitioners have lacked a robust and validated instrument for measuring long-term commitment and its dimensions in the specific context of

(c) The Author(s). 2018 Open Access This article is distributed under the terms of the Creative Commons Attribution 4.0 International License (http://creativecommons.org/licenses/by/4.0/), which permits unrestricted use, distribution, and reproduction in any medium, provided you give appropriate credit to the original author(s) and the source, provide a link to the Creative Commons license, and indicate if changes were made. 
entrepreneurship, for which most scholars have to use some survey data to measure entrepreneurial long-term commitment (Mooradian et al. 2016).

This paper uses the emigration statuses of entrepreneurs as a proxy for their long-term commitment. The intuition for developing this instrument comes from the fact about the emigration of rich Chinese entrepreneurs, which has attracted much media attention (Wall Street Journal 2014; Bloomberg 2014). Although it has complex motives, the emigration of Chinese entrepreneurs, however, has often been attributed to their lack of long-term commitment to business success in China. These entrepreneurs may have other reasons for owning foreign residency rights, such as the convenience of conducting business and better education for their children but there is some survey evidence that suggests a lack of long-term commitment is a major driving force for Chinese entrepreneurs to leave China and obtain foreign residency rights (e.g., CMB and Bain 2011; EI 2013). ${ }^{1}$

Emigration of Chinese entrepreneurs is associated with their lack of long-term commitment at least for the following two reasons. On the one hand, emigration to another country would consume these entrepreneurs a lot of valuable resources (including money, time, etc.), which can be used in domestic ventures if these entrepreneurs always stay in China. On the other hand, emigration creates diversity. Once Chinese entrepreneurs emigrate to another economic system, they may find new opportunities. The diversity lowers their risk compared to doing business only in one country.

Admitting the positive association between entrepreneurs' lack of long-term commitment and their emigration statuses, we assume that entrepreneurs have a lower sense of long-term commitment if they have foreign residency rights (hereafter called leaving entrepreneurs). Conversely, entrepreneurs have a higher sense of long-term commitment if they are domestic citizens without foreign residency rights (hereafter called staying entrepreneurs). Thus, we develop a new instrument to measure entrepreneurial long-term commitment by using entrepreneurs' emigration statuses. Specifically, we identify whether Chinese entrepreneurs have obtained foreign residency rights, by using a unique dataset of mandatorily disclosed emigration statuses of all founding entrepreneurs in Chinese IPO firms from 2006 to 2015. Acknowledging such a coarse instrument has its limitations, we use this instrument to measure entrepreneurial long-term commitment and investigate its impacts on corporate outcomes and entrepreneurs' individual behaviors.

Our data and research design have some merits. To begin with, our dataset of Chinese entrepreneurs' emigration statuses is unique. The information about emigration status of a person is ordinarily privately held so it is not mandatorily disclosed in many developed markets. Our dataset of emigration statuses of all controlling natural persons of IPO firms is selection-bias-free and provides an entire picture for Chinese entrepreneurs, making a large-sample data analysis possible. What is more, our research sample focuses on IPO firms, exploring the impacts of entrepreneurs' emigration statuses disclosed in IPO prospectuses on post-IPO corporate outcomes. Whether an entrepreneur had obtained foreign residency rights at the time of IPO is exogenous to post-IPO corporate outcomes and it is also relatively stable over time, so our focus on IPO firms serves as an ideal setting to test the causal link between entrepreneurial long-term commitment and corporate outcomes. Our research design rules out the issue of endogeneity to some extent.

In this paper, we first explore which factors are associated with Chinese entrepreneurial long-term commitment and their emigration statuses. We find that 
entrepreneurs in IPO firms that are older or larger and with better performance are more likely to have foreign residency rights and then are more likely to leave from China. This indicates that entrepreneurs have more concerns about business risk when their firms become more successful and more seasoned. We also find that entrepreneurs are more likely to leave China if they have had the experience of studying or working overseas. This indicates that entrepreneurs' individual experience affects their emigration status choices. We further find that entrepreneurs are more likely to leave China if their firms are located in Fujian, Guangdong or Shanghai. Because Fujian and Guangdong are famous hometowns of overseas Chinese and Shanghai is the Chinese economic center, this evidence indicates the impact of entrepreneurs' geographical cultural factors on their emigration status choices.

Furthermore, we investigate the impacts of entrepreneurial long-term commitment on post-IPO shareholder value and corporate outcomes. First, controlling for other explanatory variables, IPO firms controlled by leaving entrepreneurs perform $17.6 \%$ less than those firms controlled by staying entrepreneurs in terms of long-term 3-year buy and hold abnormal return (BHAR). This suggests that entrepreneurs' lack of long-term commitment leads to the deterioration of long-term shareholder value. Second, IPO firms controlled by leaving entrepreneurs also perform worse than those firms controlled by staying entrepreneurs regarding firm fundamentals. Specifically, the former firms expand in firm scale more slowly, behave worse in operating performance and bear much more debt than the latter firms do. Third, investment related empirical results indicate that leaving entrepreneurs invest less in R\&D expenditure and thus their firms have less innovation output and exhibit lower innovation efficiency in the post-IPO 3-year period. The above evidence is consistent with the argument that entrepreneurs' lack of long-term commitment leads to their relatively cutting off potential growth-relevant investment.

Whether entrepreneurial long-term commitment would affect entrepreneurs' individual behaviors is also an interesting issue. At first, we investigate whether entrepreneurs' firm control transfers are affected by their lack of long-term commitment. If Chinese entrepreneurs lack long-term commitment, and accordingly have foreign residency rights, we argue that they are more likely to transfer their corporate control power after their firms go public. The rationale for this is that because of overvaluation in Chinese stock market, going public means a great value appreciation, so Chinese entrepreneurs have a great incentive to cash out their shares and transfer their control power after their firms go public if they lack long-term commitment. Our evidence provides support for this argument. Leaving entrepreneurs are more likely to transfer their control power in the post-IPO 5-year period. Moreover, due to mandatory constraints of selling shares by controlling shareholders, ${ }^{2}$ entrepreneurs have to resign the position of chairman or CEO in advance before they make their future plans to reduce their shares without any constraint. Our empirical results indicate that leaving entrepreneurs are also more likely to resign the position of chairman or CEO in the post-IPO 4 or 5-year period. This evidence illustrates these entrepreneurs' deliberate share-selling planning.

Our paper makes the two contributions. First, we develop and test a new measurable instrument to capture the essence of entrepreneurial long-term commitment, and then, we document that entrepreneurs' lack of long-term commitment can have a direct impact on corporate outcomes, shareholder wealth and entrepreneurs' individual behaviors. To the best of our knowledge, we are among the first to document this finding at 
the firm level using a unique dataset of emigration status to proxy for entrepreneurs' long-term commitment. We also show that most entrepreneurs are rational agents, considering tradeoffs between cost and benefit to achieve optimal strategies when making some major decisions, such as cashing out their shares and leaving China. Second, using IPO sample firms provides a clean setting to test the causal link between entrepreneurs' lack of long-term commitment and corporate outcomes.

The rest of the paper proceeds as follows. In Section "Data and methodologies", we describe sample formation, key variables and empirical methodologies. In Section "Empirical results", we discuss empirical analyses and findings. Results of robustness checks are displayed in Section "Robustness checks". We conclude in Section "Conclusion".

\section{Data and methodologies}

Our sample comprises all the Chinese A-share privately owned IPO firms that went public on the Shanghai Stock Exchange (SHSE) and Shenzhen Stock Exchange (SZSE) between 2006 and 2015. We chose 2006 as the starting year because China's split share structure reform, which occurred in 2005, led to the frozen IPO market during the year of 2005, and a new set of IPO regulations became effective beginning in 2006. Under this new regulation, all new issues, including shares held by controlling persons, are theoretically tradable, which creates essentially a different incentive system for entrepreneurs compared with previous years. Focusing our sample on the same regulatory regime in the post-2005 period enables us to more precisely capture the impacts of entrepreneurs' foreign residency rights. To better understand the impacts of entrepreneurs' possession of foreign residency rights on corporate outcomes, we focus on private firms as the disclosure requirement for residency information applies only to natural persons. Hence, all the firms in our sample are privately owned, and they are not state controlled.

For each IPO firm, we hand-collect the residency information of all founding controlling persons (henceforth referred to as "entrepreneurs") from firms' IPO prospectuses, including the following information: Whether multiple controlling persons exist; whether at least one controlling person has foreign residency rights; the targeted foreign countries/regions of residency; whether this controlling person with foreign residency rights has experience of studying or working overseas, etc. The emigration statuses of entrepreneurs include three types: Chinese nationals without foreign residency rights, Chinese nationals with foreign residency rights, and foreign nationals. Our treated sample of leaving entrepreneurs includes the last two groups, and our control sample of staying entrepreneurs includes the first group. ${ }^{3}$ The relevant information is mainly disclosed in the following two sections: "Introduction of controlling shareholders and controlling persons" and "Board of directors, board of supervisors, and senior management." Because the residency information is disclosed in firms' IPO prospectuses and controlling persons' residency information is relatively stable over time, we regard the residency information as exogenous to post-IPO corporate outcomes, which makes one advantage of our identification strategy. After dropping all state-owned IPO firms, our sample comprises 1218 IPO firms, of which 171 IPO firms have at least one controlling person who has foreign residency rights.

The data of IPOs are obtained from the China Securities Market and Accounting Research (CSMAR) database. Information about firm fundamentals and stock return of IPO firms is also collected from the CSMAR database. Firm ownership data that are 
used for defining privately owned firms are obtained from the CSMAR database and the RESSET financial database (RESSET), respectively. Information about patent applications is manually collected from National Intelletual Property Administration, PRC (CNIPA, previously SIPO). We match patent data and firm financial data by firm names. We also manually check for matching accuracy. To mitigate the influence of outliers, all financial continuous variables are winsorized in the top and bottom one percentile.

\section{Empirical results}

\section{Descriptive statistics}

Table 1 provides summary statistics of our sample firms. As shown in Panel A, compared with IPO firms whose controlling persons all are Chinese nationals without foreign residency rights, those IPO firms for which there is at least one controlling person with foreign residency rights have similar firm size, but much better operating performance and lower financial leverage.

Panel B of Table 1 presents the distribution of our sample firms by calendar year. Over the span of ten years, IPO markets were more active in 2010, 2011, and 2015, but some new IPO regulatory rules were under discussion in 2013 so that the IPO market was actually frozen in that year. As shown, there is no significant yearly variation for IPO firms controlled by entrepreneurs with different emigration statuses.

Panel C of Table 1 further presents the distribution of targeted countries/regions of residency. Chinese Hong Kong, Canada and the US are the top 3 targeted regions/ countries of residency for Chinese mainland entrepreneurs.

Panel D of Table 1 reports the top 10 provinces/municipalities according to the number of IPO firms in their jurisdictional regions. Guangdong, Zhejiang and Jiangsu are ranked the top 3 with regard to the number of IPO issues. However, if we rank these provinces/municipalities according to the ratio of IPO firms whose controlling persons have foreign residency rights to total IPO firms, the top 3 ones are Shanghai, Fujian and Guangdong. Shanghai is the biggest city and the economic center in China, so overseas Chinese usually regard Shanghai as their priority investment destination. Fujian and Guangdong are well known hometowns of overseas Chinese, and many wealthy overseas Chinese entrepreneurs go back to their hometowns to invest, which can explain why there is a high ratio of entrepreneurs in these two provinces who have foreign residency rights. In the following regression model to examine which factors affect entrepreneurs' possession of foreign residency rights, we include two indicator variables to control for potential geographic explanations. Table 2 presents descriptive statistics of all main variables used in our regression models.

\section{Which factors affect entrepreneurs obtaining foreign residency rights?}

Given the importance of foreign residency rights, we are interested in exploring which factors explain entrepreneurs' possession of foreign residency rights. We introduce some potential explanatory variables in our regression. First, we include firm fundamental variables at IPO, including firm size, ROA, financial leverage and firm age to explore their association with entrepreneurs' choices of obtaining foreign residency rights. We infer that entrepreneurs in firms that are larger, seasoned, and better performer are more likely to have foreign residency rights. There are at least two reasons to argue for that. The first one is that entrepreneurs in firms that are larger, seasoned, and better 
Table 1 Univariate statistics

\begin{tabular}{|c|c|c|c|c|c|c|c|}
\hline \multicolumn{8}{|l|}{ Panel A: Summary statistics } \\
\hline & & \multicolumn{2}{|c|}{ SIZE_IPO } & \multicolumn{2}{|c|}{$R O A \_I P O$} & \multicolumn{2}{|c|}{$L E V \_I P O$} \\
\hline & No. of obs. & Mean & Median & Mean & Median & Mean & Median \\
\hline Full sample & 1218 & 20.100 & 19.993 & 0.207 & 0.176 & 0.046 & 0.000 \\
\hline With foreign residency & 171 & 20.160 & 19.980 & 0.226 & 0.194 & 0.034 & 0.000 \\
\hline Without foreign residency & 1047 & 20.090 & 19.995 & 0.204 & 0.172 & 0.048 & 0.000 \\
\hline \multicolumn{8}{|c|}{ Panel B: Distribution by year of IPO firms } \\
\hline Year & Full sample & & \multicolumn{3}{|c|}{ With foreign residency } & \multicolumn{2}{|c|}{ Without foreign residency } \\
\hline 2006 & 33 & & \multicolumn{3}{|l|}{2} & \multicolumn{2}{|l|}{31} \\
\hline 2007 & 69 & & \multicolumn{3}{|l|}{7} & \multicolumn{2}{|l|}{62} \\
\hline 2008 & 57 & & \multicolumn{3}{|l|}{3} & \multicolumn{2}{|l|}{54} \\
\hline 2009 & 88 & & \multicolumn{3}{|l|}{13} & \multicolumn{2}{|l|}{75} \\
\hline 2010 & 288 & & \multicolumn{3}{|l|}{36} & \multicolumn{2}{|l|}{252} \\
\hline 2011 & 257 & & \multicolumn{3}{|l|}{33} & \multicolumn{2}{|l|}{224} \\
\hline 2012 & 126 & & \multicolumn{3}{|l|}{25} & \multicolumn{2}{|l|}{101} \\
\hline 2013 & 1 & & \multicolumn{3}{|l|}{0} & \multicolumn{2}{|l|}{1} \\
\hline 2014 & 106 & & \multicolumn{3}{|l|}{14} & \multicolumn{2}{|l|}{92} \\
\hline 2015 & 193 & & \multicolumn{3}{|l|}{38} & \multicolumn{2}{|l|}{155} \\
\hline Total & 1218 & & \multicolumn{3}{|l|}{171} & \multicolumn{2}{|l|}{1047} \\
\hline
\end{tabular}

Panel C: Distribution of residential countries/regions

\section{Frequency}

Hong Kong, China

Canada

United States

Taiwan, China

Australia

Singapore

New Zealand

Philippines

Macao, China

Gambia

Germany

Japan

Guinea Bissau

France

Argentina

Italy

United Kingdom

Unknown

Panel D: Top 10 provinces/municipalities ranked based on number of IPO firms

Province

Full sample With foreign residency

Guangdong

253

Zhejiang

189

163

117

\section{0}

29

19

10
Beijing
50

39

19

18

18

14

6

5

3

3

2

2

2

1

1

1

1

4

Without foreign residency

203

160

144

107 
Table 1 Univariate statistics (Continued)

\begin{tabular}{llll}
\hline Shandong & 73 & 2 & 71 \\
Shanghai & 73 & 26 & 47 \\
Fujian & 48 & 15 & 33 \\
Sichuan & 38 & 3 & 35 \\
Anhui & 34 & 2 & 32 \\
Hunan & 33 & 3 & 30 \\
Other provinces & 197 & 12 & 185 \\
Total & 1218 & 171 & 1047 \\
\hline
\end{tabular}

This table provides summary statistics for our treated sample of entrepreneurs with foreign residency rights and their control sample of entrepreneurs without foreign residency rights. The sample includes 1218 non-state IPO firms for the period 2006 to 2015. Panel A provides summary statistics for the comparison variables. Panel B reports the yearly distribution of IPO firms. Panel C reports the distribution of target residential countries/regions. Panel D reports the top 10 provinces/ municipalities ranked based on number of IPO firms

Table 2 Descriptive statistics of main variables

\begin{tabular}{|c|c|c|c|c|c|c|}
\hline Variable & No. of obs. & Mean & Median & Std. Dev. & $\mathrm{P} 25$ & P75 \\
\hline DUMMY_ID & 1218 & 0.140 & 0.000 & 0.348 & 0.000 & 0.000 \\
\hline SIZE_IPO & 1215 & 20.100 & 19.993 & 0.871 & 19.489 & 20.586 \\
\hline ROA_IPO & 1215 & 0.207 & 0.176 & 0.129 & 0.123 & 0.252 \\
\hline LEV_IPO & 1196 & 0.046 & 0.000 & 0.078 & 0.000 & 0.065 \\
\hline FIRM_AGE & 1218 & 9.225 & 8.942 & 5.148 & 5.359 & 12.532 \\
\hline OVERSEAS_STUDY & 1213 & 0.073 & 0.000 & 0.261 & 0.000 & 0.000 \\
\hline OVERSEAS_WORK & 1214 & 0.065 & 0.000 & 0.247 & 0.000 & 0.000 \\
\hline MULTISHAREHOLDERS & 1214 & 0.425 & 0.000 & 0.495 & 0.000 & 1.000 \\
\hline DUMMY_SH & 1218 & 0.060 & 0.000 & 0.237 & 0.000 & 0.000 \\
\hline DUMMY_FJ_GD & 1218 & 0.209 & 0.000 & 0.407 & 0.000 & 0.000 \\
\hline BHAR_3YEAR & 917 & 0.399 & 0.083 & 1.160 & -0.212 & 0.624 \\
\hline TREATED & 918 & 0.130 & 0.000 & 0.336 & 0.000 & 0.000 \\
\hline UNDERPRICE_MKTADJ & 918 & 0.558 & 0.330 & 0.754 & 0.115 & 0.721 \\
\hline OFFER_SIZE & 918 & 17.161 & 17.099 & 0.547 & 16.760 & 17.504 \\
\hline LEADERUNDERWRITER & 918 & 0.386 & 0.000 & 0.487 & 0.000 & 1.000 \\
\hline LOG_SALES & 5513 & 20.231 & 20.118 & 1.058 & 19.484 & 20.884 \\
\hline LOG_EMPLOY & 4820 & 6.848 & 6.811 & 0.947 & 6.189 & 7.471 \\
\hline$R O A$ & 4594 & 0.127 & 0.097 & 0.127 & 0.051 & 0.168 \\
\hline LEV & 5463 & 0.030 & 0.000 & 0.061 & 0.000 & 0.034 \\
\hline CAPEX_TA & 4590 & 0.116 & 0.086 & 0.104 & 0.045 & 0.154 \\
\hline LOG_RD & 5481 & 2.021 & 0.000 & 5.257 & 0.000 & 0.000 \\
\hline LOG_PATENT & 5481 & 1.824 & 1.946 & 1.441 & 0.000 & 2.890 \\
\hline PATENT_RD & 713 & 0.093 & 0.011 & 0.370 & 0.002 & 0.046 \\
\hline POST & 5513 & 0.500 & 0.000 & 0.500 & 0.000 & 1.000 \\
\hline DUMMY_TANSFER_60M & 787 & 0.053 & 0.000 & 0.225 & 0.000 & 0.000 \\
\hline DUMMY_RESIGN_6OM & 787 & 0.093 & 0.000 & 0.290 & 0.000 & 0.000 \\
\hline DUMMY_RESIGN_48M & 787 & 0.056 & 0.000 & 0.230 & 0.000 & 0.000 \\
\hline
\end{tabular}


performer have a higher business risk and thus are more inclined to own foreign residency statuses. The second one is that because obtaining foreign residency statuses needs certain financial resources, entrepreneurs in firms that are larger, seasoned, and better performer are more capable to undertake it.

Second, we include two entrepreneur individual trait variables in our regression. The two variables are whether at least one controlling person has experience of studying overseas (OVERSEAS_STUDY) and whether at least one controlling person has experience of working overseas (OVERSEAS_WORK), respectively. If a person has experience of studying or working overseas, he/she is more likely to apply for and obtain foreign residency rights.

Third, we include three indicator variables to explore other potential effects. The first one is whether the IPO firm has multiple shareholders (MULTISHAREHOLDERS). If a firm has multiple controlling natural person shareholders, there will be a higher probability for this firm to have at least one controlling person who owns foreign residency rights. The second and third ones are related to the abovementioned geographic factors. We include two dummy variables: Whether an IPO firm locates in the provinces of Fujian or Guangdong (DUMMY_FJ_GD) and whether an IPO firm locates in the city of Shanghai (DUMMY_SH) in our regression.

Table 3 provides the logit regression results. The marginal effects are also presented. As shown in Table 3, entrepreneurs in IPO firms that are larger, perform better, or older are more likely to have foreign residency rights. Moreover, entrepreneurs' experiences of studying or working overseas are significantly associated with their possession of foreign residency rights. We also find that firms with multiple controlling shareholders are more likely to have at least one controlling person who has foreign residency rights. Finally, entrepreneurs in Fujian, Guangdong and Shanghai are more likely to have foreign residency rights, which is consistent with our univariate analysis.

Table 3 Factors affect entrepreneurs' possession of foreign residency rights

\begin{tabular}{lll}
\hline & \multicolumn{1}{l}{ DUMMY_ID } & \\
\cline { 2 - 3 } & $(1)$ & Marginal effects (dy/dx) \\
\hline SIZE_IPO & $0.380^{\mathrm{a}}(4.72)$ & 0.034 \\
ROA_IPO & $2.653^{\mathrm{a}}(9.82)$ & 0.238 \\
LEV_IPO & $-1.323(-1.46)$ & -0.119 \\
FIRM_AGE & $0.053^{\mathrm{a}}(11.50)$ & 0.005 \\
OVERSEAS_STUDY & $0.581^{\mathrm{b}}(1.98)$ & 0.052 \\
OVERSEAS_WORK & $3.386^{\mathrm{a}}(22.74)$ & 0.304 \\
MULTISHAREHOLDERS & $0.672^{\mathrm{a}}(7.37)$ & 0.060 \\
DUMMY_SH & $1.558^{\mathrm{a}}(8.68)$ & 0.140 \\
DUMMY_FJ_GD & $0.757^{\mathrm{a}}(7.32)$ & 0.068 \\
Industry fixed effects included? & Yes & \\
No. of obs. & 1161 & \\
Pseudo $R^{2}$ & 0.273 & \\
\hline
\end{tabular}

This table presents results of a logit regression of entrepreneurs' possession of foreign residency rights on some firm, region and individual characteristics. The table shows the baseline estimation results, along with marginal effects. $t$-values are reported in parentheses. Standard error is clustered at the industry level. The sample includes 1218 non-state IPO firms for the period 2006 to 2015 . See Appendix for variable definitions

$a, b$, and ${ }^{c}$ stand for significance at the 1,5 , and $10 \%$ level, respectively 


\section{Effect of foreign residency rights on post-IPO long-term stock return}

We first present the results on the relationship between entrepreneurs' possession of foreign residency rights and long-term stock return. Table 4 provides the results for the univariate analysis and OLS regressions examining the impact of entrepreneurs' foreign residency rights on the post-IPO buy-and-hold abnormal returns (BHARs).

Panel A of Table 4 illustrates a univariate analysis of 1-year to 3-year BHARs for our full sample and its subsamples. The mean and median of post-IPO 3-year BHAR for the firms controlled by staying entrepreneurs are 41.7 and $9.3 \%$, respectively, whereas they are only 27.7 and $-4.3 \%$ for those firms controlled by leaving entrepreneurs. The differences in BHAR for these two groups are all negative $(-14$ and $-13.6 \%$, respectively), but only the median difference is statistically significant at the $10 \%$ level. Such evidence suggests that whether entrepreneurs are leaving or staying may affect shareholder wealth in the long run. Furthermore, we run a logit model to estimate the likelihood that the firm has a leaving entrepreneur using all variables in Table 3 and then we

Table 4 Effects of foreign residency rights on Post-IPO buy-and-hold abnormal returns

\begin{tabular}{|c|c|c|c|c|c|c|c|}
\hline \multicolumn{8}{|l|}{ Panel A: Univariate analysis } \\
\hline & & \multicolumn{2}{|c|}{ BHAR_IYEAR } & \multicolumn{2}{|c|}{ BHAR_2YEAR } & \multicolumn{2}{|c|}{ BHAR_3YEAR } \\
\hline & No. of obs. & Mean & Median & Mean & Median & Mean & Median \\
\hline Full sample & 918 & $-0.060^{\mathrm{a}}$ & $-0.113^{\mathrm{a}}$ & $0.104^{\mathrm{a}}$ & -0.058 & $0.399^{\mathrm{a}}$ & $0.083^{\mathrm{a}}$ \\
\hline (1) With foreign residency & 119 & $-0.081^{a}$ & $-0.139^{\mathrm{a}}$ & 0.085 & -0.115 & $0.277^{\mathrm{a}}$ & $-0.043^{c}$ \\
\hline (2)Without foreign residency & 799 & $-0.057^{\mathrm{a}}$ & $-0.112^{\mathrm{a}}$ & $0.106^{\mathrm{a}}$ & -0.048 & $0.417^{\mathrm{a}}$ & $0.093^{\mathrm{a}}$ \\
\hline $\operatorname{Diff}(1-2)$ & & -0.024 & -0.027 & -0.022 & -0.067 & -0.140 & $-0.136^{c}$ \\
\hline Matched sample & 454 & $-0.078^{\mathrm{a}}$ & $-0.128^{\mathrm{a}}$ & $0.080^{\mathrm{a}}$ & -0.091 & $0.371^{\mathrm{a}}$ & $0.034^{a}$ \\
\hline (3) With foreign residency & 116 & $-0.078^{b}$ & $-0.136^{\mathrm{a}}$ & 0.087 & -0.118 & $0.284^{\mathrm{a}}$ & $-0.044^{c}$ \\
\hline (4) Without foreign residency & 338 & $-0.077^{\mathrm{a}}$ & $-0.119^{\mathrm{a}}$ & $0.077^{\mathrm{b}}$ & -0.085 & $0.401^{a}$ & $0.070^{\mathrm{a}}$ \\
\hline Diff(3-4) & & -0.001 & -0.017 & 0.010 & -0.033 & -0.118 & -0.114 \\
\hline
\end{tabular}

Panel B: Regression results

\begin{tabular}{cc}
\multicolumn{2}{c}{ BHAR_3YEAR } \\
Full sample & Matched sample \\
$(1)$ & $(2)$ \\
$-0.176^{\mathrm{a}}(-4.72)$ & $-0.115^{\mathrm{c}}(-1.92)$ \\
$-0.320^{\mathrm{a}}(-18.37)$ & $-0.399^{\mathrm{a}}(-4.40)$ \\
$-0.187^{\mathrm{a}}(-5.50)$ & $-0.189(-1.22)$ \\
$-0.419(-1.32)$ & $-0.631(-1.04)$ \\
$-0.212(-1.47)$ & $0.474(0.99)$ \\
$-0.186^{\mathrm{a}}(-3.11)$ & $-0.169(-0.79)$ \\
$0.086^{\mathrm{c}}(1.87)$ & $-0.026(-0.27)$ \\
Yes & Yes \\
Yes & Yes \\
898 & 454 \\
0.247 & 0.227 \\
\hline
\end{tabular}

TREATED

UNDERPRICE_MKTADJ

SIZE_IPO

ROA_IPO

$\angle E V_{-} I P O$

OFFER_SIZE

LEADERUNDERWRITER

Industry fixed effects included?

Year fixed effects included?

No. of obs,

0.247

0.227

This table presents results of univariate analysis and regression analysis for post-IPO buy-and-hold abnormal returns (BHARs). Panel A presents the univariate tests on 1-year, 2-year and 3-year BHARs for full sample and matched sample respectively. Panel B reports the OLS results for BHAR_3YEAR. t-values are reported in parentheses. Standard error is clustered at the industry level. The sample includes 918 non-state IPO firms for the period 2006 to 2012 that have the post-IPO period of at least 3 years. See Appendix for variable definitions

$\mathrm{a}, \mathrm{b}$, and ${ }^{\mathrm{c}}$ stand for significance at the 1,5 , and $10 \%$ level, respectively 
match each of our treated firms to three control firms with the closest propensity score in the same IPO year and the same industry. We presents post-IPO BHARs for this matched sample. The mean and median of post-IPO 3-year BHAR for the firms controlled by leaving entrepreneurs are 28.4 and $-4.4 \%$, respectively, whereas they are 40.1 and $7 \%$ for those firms controlled by matched staying entrepreneurs. The comparisons of post-IPO 1-year and 2-year BHARs show that firms controlled by leaving entrepreneurs also perform worse than those firms controlled by staying entrepreneurs in the periods of post-IPO 1-year and 2-year, but their differences are not statistically significant.

Panel B of Table 4 further presents the OLS results used to analyze the effects of entrepreneurs' possession of foreign residency rights on post-IPO 3-year BHAR. A main variable of interest in the regression models is an indicator variable, TREATED, which takes the value 1 if the sample firm has at least one leaving entrepreneur among its controlling persons and 0 otherwise. Market-adjusted underpricing, firm size, ROA, leverage and IPO offer size are also included in our regression model to control for firm fundamental characteristics. We include an indicator variable, LEADUNDERWRITER, to control for the effects of lead underwriter on BHAR, which equals 1 if the sample firm is underwritten by one of top 10 underwriters that are ranked according to the market share of underwritten new share issues in the previous year. We also include industry (classified by China Securities Regulatory Commission, CSRC) and year fixed effects. The coefficient on TREATED in Column (1), which uses full sample firms in the regression, is $-17.6 \%$ and is significant at the $1 \%$ level, indicating that compared with firms controlled by staying entrepreneurs, those firms controlled by leaving entrepreneurs are more likely to perform worse in the long run. The above result is consistent with our univariate analysis. All other variables in the regression model are loaded with coefficients that are generally consistent with theoretical predictions. For example, firms with greater underpricing, larger firm size and higher IPO offer size are more likely to perform worse in the long run, but firms underwritten by lead underwriters tend to perform better in the long run, which corroborates the theory of lead underwriter certification (Carter et al. 1998).

In Column (2), we further use matched sample firms, which include firms controlled by leaving entrepreneurs and three propensity score matched firms that are controlled by staying entrepreneurs, in the regression. Although the coefficient of TREATED in Column (2) is reduced to be significant at $10 \%$ level, its value is still negative $(-11.5 \%)$. The result shows that the assertion that firms controlled by leaving entrepreneurs are long-term value destroyer is not driven by some firm fundamental factors.

\section{Effect of foreign residency rights on post-IPO corporate outcomes}

The above evidence indicates that entrepreneurs' possession of foreign residency rights is associated with post-IPO stock underperformance in the long run. We further explore the relationship between foreign residency rights and post-IPO firms' expansion and their employment as well as the effects of foreign residency rights on firms' other real outcomes, such as operating performance and financial leverage. Table 5 presents the results for the proxies of firm fundamentals. Difference-in-differences (DID) models are used as our regression models. We choose firms controlled by leaving entrepreneurs as our treated sample and all other sample firms as the control sample. The sample period covers the 3 years around the IPO. The dummy variable POST is coded as 
Table 5 Effects of foreign residency rights on Post-IPO firm size and performance

\begin{tabular}{lcccc}
\hline & LOG_SALES & LOG_EMPLOY & ROA & LEV \\
& $(1)$ & $(2)$ & $(3)$ & $(4)$ \\
\hline TREATEDXPOST & $-0.070^{\mathrm{a}}(-3.22)$ & $-0.108^{\mathrm{b}}(-2.16)$ & $-0.017^{\mathrm{b}}(-2.53)$ & $0.004^{\mathrm{c}}(2.00)$ \\
TREATED & $0.088(1.44)$ & $0.106(1.55)$ & $0.022^{\mathrm{b}}(2.72)$ & $-0.010^{\mathrm{a}}(-2.99)$ \\
POST & $0.550^{\mathrm{a}}(14.72)$ & $0.428^{\mathrm{a}}(10.87)$ & $-0.147^{\mathrm{a}}(-14.44)$ & $-0.004(-1.57)$ \\
Industry fixed effects included? & Yes & Yes & Yes & Yes \\
No. of obs. & 5513 & 4820 & 4594 & 5463 \\
Adjusted $R^{2}$ & 0.211 & 0.114 & 0.347 & 0.053
\end{tabular}

This table presents DID results for main variables of firm outcomes around IPO. t-values are reported in parentheses. The sample includes 918 non-state IPO firms for the period 2006 to 2012 that have the post-IPO period of at least 3 years. See Appendix for variable definitions

$\mathrm{a}, \mathrm{b}$, and ${ }^{\mathrm{c}}$ stand for significance at the 1,5 , and $10 \%$ level, respectively

follows: If the sample period lies in the current IPO year, and the previous $t-1$ and $t-2$ year, POST equals 0; if the sample period lies in the first to third year after current IPO year, POST equals 1. Column (1) uses the natural logarithm of firm sales (LOG_SALES) as the dependent variable. As reported, the coefficient of TREATED $\times P O S T$ is negative and significant at the $1 \%$ level, which indicates that firms controlled by leaving entrepreneurs are more likely to perform worse with regards to sales growth. Column (2) further presents the results for the natural logarithm of the number of hired employees (LOG_EMPLOY) and the result indicates that firms controlled by leaving entrepreneurs have a worse record with regards to employment growth. Columns (3) and (4) further present the results for operating performance $(R O A)$ and financial leverage $(L E V)$, respectively. As reported, we find that compared with control firms, firms controlled by leaving entrepreneurs have worse post-IPO firm operating performance and have higher financial leverage.

Combining the above evidence for firm fundamentals, we conclude that leaving entrepreneurs are more likely not to broaden firm size but to shrink firm size and their firms are also worse performer and more highly levered. All these reflect worse firm prospects, which can explain post-IPO stock underperformance.

\section{Effect of foreign residency rights on post-IPO investment and innovation}

A possible explanation for the above evidence is that these leaving entrepreneurs lack long-term commitment, which not only urges them to apply for and obtain foreign residency rights, but also makes them lack confidence to Chinese long-term development, so they shrink firm size.

Table 6 presents direct evidence related to firm investment and innovation. The model specifications are still the DID ones, and we keep the sample period as the one used in Table 5. Column (1) presents the results for the ratio of capital expenditure to total assets (CAPEX_TA). As shown, we do not find any significant difference between our treated sample and control sample with regarding to capital expenditure. Column (2) presents the results for natural logarithm of $(1+\mathrm{R} \& \mathrm{D}$ expenditure) (LOG_RD). The coefficient of TREATED $\times P O S T$ is significantly negative at the $1 \%$ level, which indicates that firms controlled by leaving entrepreneurs are more likely to cut off their R\&D expenditure. Columns (3) and (4) explore the effects on innovation outcomes and innovation efficiency. Column (3) uses natural logarithm of (1 + number of patent applications) (LOG_PATENT) as the dependent variable to proxy for innovation outcome. 
Table 6 Effects of foreign residency rights on Post-IPO firm investment and innovation

\begin{tabular}{lcccc}
\hline & CAPEX_TA & LOG_RD & LOG_PATENT & PATENT_RD \\
& $(1)$ & $(2)$ & $(3)$ & $(4)$ \\
\hline TREATEDXPOST & $-0.002(-0.24)$ & $-0.732^{\mathrm{a}}(-7.30)$ & $-0.183^{\mathrm{a}}(-4.89)$ & $-0.085^{\mathrm{a}}(-8.57)$ \\
TREATED & $0.001(0.09)$ & $0.055(0.18)$ & $0.037(1.06)$ & $0.035^{\mathrm{a}}(4.48)$ \\
POST & $-0.044^{\mathrm{a}}(-11.89)$ & $1.811^{\mathrm{a}}(4.40)$ & $0.459^{\mathrm{a}}(16.60)$ & $-0.034(-1.24)$ \\
Industry fixed effects included? & Yes & Yes & Yes & Yes \\
No. of obs. & 4590 & 5481 & 5481 & 713 \\
Adjusted $R^{2}$ & 0.071 & 0.072 & 0.117 & -0.005 \\
\hline
\end{tabular}

This table presents DID results for main variables of firm outcomes around IPO. $t$-values are reported in parentheses. The sample includes 918 non-state IPO firms for the period 2006 to 2012 that have the post-IPO period of at least 3 years. See Appendix for variable definitions

$\mathrm{a}, \mathrm{b}$, and ${ }^{\mathrm{c}}$ stand for significance at the 1,5 , and $10 \%$ level, respectively

The results of Column (3) indicate that our treated sample firms have worse innovation outcomes in the post-IPO 3 years. Column (4) uses the ratio of the number of patent application to R\&D expenditure (PATENT_RD) to measure innovation efficiency and the results in Column (4) indicate that firms controlled by leaving entrepreneurs have deteriorating innovation efficiency in the post-IPO 3 years.

Overall, we find that leaving entrepreneurs are more likely to cut research and development expenditure, and their firms' innovation output and innovation efficiency also accordingly deteriorate. This provides further support for long-term stock underperformance.

\section{Effect of foreign residency rights on post-IPO corporate control transfer}

The above evidence indicates that firms controlled by leaving entrepreneurs perform worse not only regarding shareholder wealth creation but also regarding firm fundamentals. The possible explanation for that is that these leaving entrepreneurs have plans for leaving China (owning foreign residency rights is a signal), so they have no passion for running their firms identically to their peer entrepreneurs. We directly explore whether leaving entrepreneurs are more likely to transfer their firm control after their firms go public.

Before doing that, it should be noticed that in China, there are some mandatory regulatory rules that restrict founding entrepreneurs of IPO firms to sell their shares freely on the public market. Generally, the founding shareholders are usually entitled to freely sell their shares at least 36 months after IPO. If the founding shareholder takes a role as a director, supervisor or senior manager, his shares transferred every year shall not surpass $25 \%$ of his total shares of equity.

Table 7 provides the results for the univariate analysis and OLS regressions examining the impact of entrepreneurs' foreign residency rights on the post-IPO firm control transfer. Our sample number decreases from 1218 to 787 as we limit our sample firms to those firms that were listed for at least 5 years. As shown in Panel A of Table 7, for 787 sample firms, on average, 42 firms have firm control transfer in the post-IPO 5 years, accounting for $5.34 \%$, but for 93 sample firms controlled by leaving entrepreneurs, 9 firms (accounting for 9.68\%) have control transfer. This ratio is only $4.76 \%$ for firms controlled by staying entrepreneurs. The difference test shows that firms controlled by leaving entrepreneurs are more likely to transfer firm control power than those controlled by staying entrepreneurs. As mentioned earlier, to ease selling shares in the secondary market or even control transfer under Chinese regulatory rules, 
Table 7 Effects of foreign residency rights on Post-IPO firm control transfer

$\begin{array}{ccc}\text { Control transfer in } & \text { Resign from chairman or } & \text { Resign from chairman or } \\ \text { post-IPO } 5 \text { years } & \text { CEO positions in post-IPO } & \text { CEO positions in post-IPO } \\ & 5 \text { years } & 4 \text { years }\end{array}$

No. of firms Number Percentage (\%) Number Percentage (\%) Number Percentage (\%)

Panel A: Summary statistics

$\begin{array}{lccccccc}\text { Full sample used } & 787 & 42 & 5.34 & 73 & 9.28 & 44 & 5.59 \\ \begin{array}{l}\text { (1) with foreign } \\ \text { residency }\end{array} & 93 & 9 & 9.68 & 15 & 16.13 & 6 & 6.45 \\ \begin{array}{l}\text { (2) without } \\ \text { foreign } \\ \text { residency }\end{array} & 694 & 33 & 4.76 & 58 & 8.36 & 38 & 5.48 \\ \text { Diff (1-2) } & & & & & & & \\ \end{array}$

Panel B: Logit regression results

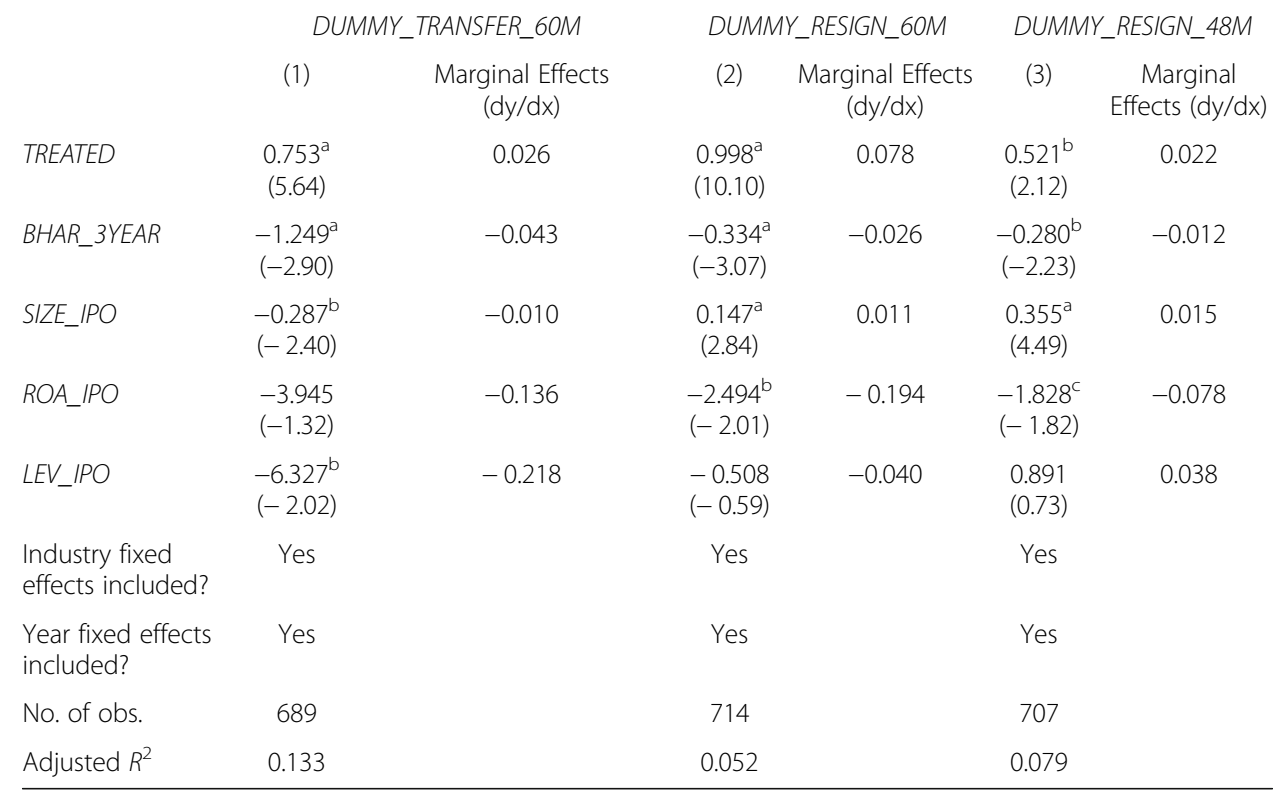

This table presents results of univariate analysis and logit regression of firm control transfer and whether an entrepreneur resigns from chairman or CEO positions. The sample includes 787 non-state IPO firms for the period 2006 to 2010 that have the post-IPO period of at least 5 years. Panel A presents the summary statistics on firm control transfer and whether an entrepreneur resigns from chairman or CEO positions for our treated sample of entrepreneurs with foreign residency rights and their control sample of entrepreneurs without foreign residency rights. Panel B reports the logit regression results for firm control transfer and whether an entrepreneur resigns from chairman or CEO positions. $t$ values are reported in parentheses. See Appendix for variable definitions

${ }^{a}, b$, and ${ }^{c}$ stand for significance at the 1,5 , and $10 \%$ level, respectively

Chinese entrepreneurs have to resign their positions as chairman or CEO at the first step. Panel A of Table 7 further shows that leaving entrepreneurs are more likely to resign the position of chairman or CEO in the post-IPO 5-years.

Panel B of Table 7 presents the OLS results. We use whether the sample firm has control transfer in post-IPO 5 years (DUMMY_TRANSFER_60M) as the dependent variable in Column (1). The results in Column (1) are consistent with our univariate analysis. Leaving entrepreneur is positively associated at the $1 \%$ level significance level with higher probability of control transfer. We further use whether entrepreneurs resign the position of chairman or CEO in the post-IPO 5 years (DUMMY_RESIGN_60M) and whether entrepreneurs resign the position of chairman or CEO in the post-IPO 4 years (DUMMY_RESIGN_48M) as dependent variables respectively. The results in Columns (2) and (3) indicate that leaving entrepreneurs are more likely to 
resign the position of chairman or CEO in the post-IPO 4 or 5 years, which reflects their deliberate share-selling planning.

\section{Robustness checks}

We conduct multiple supplement analyses to explore the robustness of the above results. First, our treated sample of leaving entrepreneurs contains both entrepreneurs who are Chinese mainland citizens with foreign residency rights and entrepreneurs who are foreign nationals or citizens from Chinese Hong Kong, Chinese Macau and Chinese Taiwan. The two groups of entrepreneurs may have some different motives and preferences in doing business in Chinese mainland, so we restrict our treated sample to those entrepreneurs who are only Chinese mainland citizens with foreign residency rights and replicate the above tests and find our main results are similar.

Second, our treated sample of leaving entrepreneurs includes 96 Chinese mainland citizens with foreign residency rights, in which 19 Chinese entrepreneurs have experience of studying or working overseas. One concern is that the incentives of entrepreneurs who have experiences of studying or working overseas are likely to be different from those who do not have such experiences, so it is worthwhile to empirically differentiate these two types of entrepreneurs due to possible different levels of (lack of) long-term commitment. To alleviate such concern, we drop these leaving entrepreneurs with experiences of studying or working overseas from our treated sample and then replicate all empirical analyses. Our main results basically do not change.

The third concern is that because there may be huge differences in firm fundamentals between firms controlled by leaving entrepreneurs (treated sample) and those firms controlled by staying entrepreneurs (control sample), our main results are driven by these differentiated firm fundamentals. To address such concern, instead of using all staying entrepreneurs as our control firms, we select propensity score matched firms for our sample firms of leaving entrepreneurs to mitigate the influence of confounding factors. We run a logit model to estimate the likelihood that the firm has a leaving entrepreneur using all variables in Table 3 and then we match each of our treated firms to three control firms with the closest propensity score in the same IPO year and the same industry. We use the newly formed sample to replicate the tests in Tables 5, 6 and 7 and find our main results essentially do not change.

Fourth, the basic regression model used in our paper applies DID methodlogy. We check the parallel trends of treated and control groups before treated and find that there are no significant pre-treated parallel trends in our main variables of interest.

\section{Conclusion}

The emigration of Chinese entrepreneurs has become a public issue, but empirical analyses are still sparse due to data limitations. We offer a large sample analysis using a unique dataset of Chinese entrepreneurs' emigration statuses to develop and test an instrument in order to measure entrepreneurial long-term commitment. We find that Chinese entrepreneurs' foreign residency rights leads to long-term shareholder wealth deterioration and worse firm performance. Implications are provided in the following aspects.

First of all, the emigration of some wealthy Chinese entrepreneurs has attracted much media attention and its causes and effects have been discussed. Emigrations of Chinese entrepreneurs can be driven by political, educational and environmental issues. 
Accompanying leaving entrepreneurs are not only their family and their wealth but also some indispensable resources necessary to Chinese future development, including technology, connections, and even entrepreneurship spirit. There is also a public concern that entrepreneurs do business recklessly just for money if they have foreign residency rights as their reserve. In response to the public concerns about leaving entrepreneurs, on January 6, 2003, China Securities Regulatory Commission (CSRC) required IPO firms to disclose their controlling shareholders' identity information. As a material corporate matter, public firms are also required to disclose change information of controlling persons' foreign residency. ${ }^{4}$ Our evidence suggests that entrepreneurs' emigration status affects their corporate outcomes and provides support to the stricter information disclosure about emigration statuses of controlling shareholders in Chinese public firms.

Our paper additionally contributes to the entrepreneurship literature that aims to discuss whether and how entrepreneurs shape corporate culture and ethics. Extensive research on entrepreneurship has studied the effects of enduring personality traits, which include the need for achievement, risk taking, autonomy, locus of control, and self-efficacy (Stewart Jr et al. 1998; Zhao and Seibert 2006; Rauch and Frese 2007; Zhao et al. 2010; Shane and Nicolaou 2015) as well as the effects of many non-personality differences such as gender, business experience, education, prior knowledge, network activities, and even parenting style (Duchesneau and Gartner 1990; Jo and Lee 1996; Lee and Tsang 2001; Schmitt-Rodermund 2004; Shane 2004). As a personality trait, long-term commitment has been proven a predictor of success in areas such as education, military training, and income (Díaz et al. 2013; Maddi et al. 2013). Mooradian et al. (2016) show that long-term commitment can also be used to predict entrepreneurs' success. ${ }^{5}$ We add to this literature by developing and testing a new instrument of entrepreneurial long-term commitment and its effects on corporate outcomes.

Moreover, our paper contributes to the finance literature that aims to establish and quantify systematic managerial influences on firm policies and value. Several influential studies examine whether CEO-specific styles affect firm policies (see Bertrand and Schoar 2003; Bamber et al. 2010; Graham et al. 2012; Fee et al. 2013). Prior work further shows that at least part of the heterogeneity in CEOs' managerial styles reflects variation in individual life and career experiences (e.g., Graham and Narasimhan 2005; Malmendier and Tate 2005; Malmendier et al. 2011; Benmelech and Frydman 2015; Dittmar and Duchin 2016; Schoar and Zuo 2017). We add to this literature by showing that as a core stakeholder, entrepreneurs' personality traits play a role in shaping corporate policies.

Finally, our paper contributes to the literature on IPO long-term underperformance. Since Ritter (1991) documented the long run underperformance of IPOs, a number of studies have sought to link this intriguing performance puzzle to factors such as information asymmetry, market condition, earnings management, underwriter reputation, firm maturity and other firm level factors (Reilly 1977; Ritter 1991; Jain and Kini 1994; Brav and Gompers 1997; Mikkelson et al. 1997; Teoh et al. 1998; Carter et al. 1998; Brau et al. 2012). We add to the literature by showing that entrepreneurial personality traits are one of driving factors that affect IPO long-term underperformance. 


\section{Appendix}

Table 8 Variable definition and description

\begin{tabular}{|c|c|}
\hline Variable name & Definition \\
\hline TREATED & $\begin{array}{l}\text { Indicator variable: Equals } 1 \text { if the sample firm has at least one controlling shareholder } \\
\text { with foreign residency rights; } 0 \text { otherwise }\end{array}$ \\
\hline POST & $\begin{array}{l}\text { Indicator variable: Equals } 1 \text { if the sample period lies in the post-IPO } 3 \text {-year period of } t+1 \\
\text { to } t+3 \text { year; } 0 \text { if the sample period lies in the IPO current year, and the pre-IPO } 2 \text {-year } \\
\text { period of } t-1 \text { to } t-2 \text { year }\end{array}$ \\
\hline UNDERPRICE_MKTADJ & $\begin{array}{l}\text { Market adjusted IPO underpricing: Calculated as (close price at IPO first day/IPO price)-1) } \\
\text { minus market return from IPO issue to listing }\end{array}$ \\
\hline BHAR_TYEAR & $\begin{array}{l}\text { Buy-and-hold abnormal return (BHAR) during the post-IPO 1-year with total } \\
\text { value-weighted return as the market index }\end{array}$ \\
\hline BHAR_2YEAR & $\begin{array}{l}\text { Buy-and-hold abnormal return (BHAR) during the post-IPO 2-year with total } \\
\text { value-weighted return as the market index }\end{array}$ \\
\hline BHAR_3YEAR & $\begin{array}{l}\text { Buy-and-hold abnormal return (BHAR) during the post-IPO 3-year with total } \\
\text { value-weighted return as the market index }\end{array}$ \\
\hline SIZE_IPO & Company size at IPO: Calculated as natural log of book value of total assets \\
\hline ROA_IPO & ROA at IPO: Calculated as operating income/lagged total assets \\
\hline LEV_IPO & Leverage at IPO: Calculated as long-term debt/total assets \\
\hline OFFER_SIZE & IPO issue size: Calculated as natural log of new shares issues \\
\hline FIRM_AGE & IPO firm age: Calculated as the yearly distance between firm establishment and IPO date \\
\hline LEADUNDERWRITER & $\begin{array}{l}\text { Indicator variable: Equals } 1 \text { if an underwriter is ranked as one of the top } 10 \text { underwriters } \\
\text { according to the underwritten new share issue in the previous year; and } 0 \text { otherwise }\end{array}$ \\
\hline LOG_SALES & Natural log of sales \\
\hline LOG_EMPLOY & Natural log of number of employees \\
\hline$R O A$ & Operating income/lagged total assets \\
\hline LEV & Long-term debt/total assets \\
\hline CAPEX_TA & Investment on fixed assets, intangible assets and other long-term assets/total assets \\
\hline LOG_RD & Natural log of $(1+R \& D$ expenditure $)$ \\
\hline LOG_PATENT & Natural log of ( $1+$ number of patent applications) \\
\hline PATENT_RD & (Number of patent application/R\&D expenditure) $\times 10,000$ \\
\hline
\end{tabular}

\section{Endnotes}

${ }^{1}$ The CMB and Bain (2011) survey is downloaded at http://news.hexun.com/2011/ 2011srcf/. The EI (2013) survey is downloaded at http://www.eeo.com.cn/zt/2013/caifu/.

${ }^{2}$ Different rules regulate selling shares by shareholders and high-level management. According to the Administrative Regulations implemented by China Securities Regulatory Commission (CSRC), during the tenure of directors, supervisors and senior managers in listed companies, shares transferred every year shall not surpass $25 \%$ of their total shares equity. A shareholder who currently does not serve in the position of director, supervisor and senior manager does not have to abide by this rule.

${ }^{3}$ We put the sample from Chinese Hong Kong, Chinese Macao and Chinese Taiwan in the group outside Chinese mainland. In alternative analyses (un-tabulated), we combine them with our domestic sample to construct our treated sample and show that our conclusion is not sensitive to this classification.

${ }^{4}$ Chen et al. (2018) use annual report information on foreign residency rights of controlling persons to examine whether Chinese firms whose controlling persons have foreign residency rights are more likely to engage in corporate fraud. They find a positive association between them. 
${ }^{5}$ They borrow the word "Grit" from Duckworth et al. (2011) to refer to long-term commitment. "Grit" has been defined as "the tendency to pursue long-term challenging goals with perseverance and passion" (Duckworth et al. 2011) or "trait-level perseverance and passion for long-term goals" (Duckworth et al. 2007; Duckworth and Quinn 2009).

\section{Funding}

This study was not funded by any organization.

\section{Availability of data and materials}

All data and materials used in this research are publicly available. The data of foreign residency rights of controlling persons is manually collected from IPO prospectuses. Please contact author for data requests.

\section{Authors' contributions}

DK and MW jointly conceived of the study and participated in its research design. XZ carried out data collection and data processing. All authors read and approved the final manuscript.

\section{Competing interests}

The authors declare that they have no competing interests.

\section{Publisher's Note}

Springer Nature remains neutral with regard to jurisdictional claims in published maps and institutional affiliations.

\section{Author details}

${ }^{1}$ School of Economics, Huazhong University of Science and Technology, Wuhan, China. ${ }^{2}$ School of Banking and Finance, University of International Business and Economics, 10 Huixindong Street, Chaoyang District, Beijing 100029, China. ${ }^{3}$ Management School, Queen's University Belfast, Belfast, Northern Ireland.

Received: 25 July 2018 Accepted: 1 October 2018

Published online: 19 October 2018

\section{References}

Bamber, L., Jiang, J., \& Wang, I. (2010). What's my style? The influence of top managers on voluntary corporate financial disclosure. The Accounting Review, 85, 1131-1162.

Benmelech, E., \& Frydman, C. (2015). Military CEOs. Journal of Financial Economics, 117(1), 43-59.

Bertrand, M., \& Schoar, A. (2003). Managing with style: The effect of managers on firm policies. Quarterly Journal of Economics, $118,1169-1208$.

Bloomberg, 2014. Almost half of China's rich want to emigrate. Reporter: Dexter Roberts, September 15. Downloaded at: https://www.bloomberg.com/news/articles/2014-09-15/almost-half-of-chinas-rich-want-to-emigrate.

Brau, J. C., Couch, R. B., \& Sutton, N. K. (2012). The desire to acquire and IPO long-run underperformance. Journal of Financial and Quantitative Analysis, 47, 493-510.

Brav, A., \& Gompers, P. A. (1997). The long run underperformance of initial public offerings: Evidence from venture and nonventure capital-backed companies. Journal of Finance, 52, 1791-1821.

Carter, R., Dark, F. H., \& Singh, A. K. (1998). Underwriter reputation, initial returns, and the long-run performance of IPO stocks. Journal of Finance, 53, 285-311.

Chen, D. H., Chen, Y. Y., Li, O., \& Ni, C. K. (2018). Foreign residency rights and corporate fraud. Journal of Corporate Finance, 51, 142-163.

CMB \& Bain, 2011. China's private wealth report. China merchant Bank and Bain \& company. Downloaded at: http://news. hexun.com/2011/2011srcf/.

Díaz, J. J., O Arias and DV Tudela, (2013). Does perseverance pay as much as being smart? The returns to cognitive and noncognitive skills in urban Peru. Working paper. World Bank, Washington.

Dittmar, A., \& Duchin, R. (2016). Looking in the rearview mirror: The effect of managers' professional experience on corporate financial policy. Review of Financial Studies, 29, 565-602.

Duchesneau, D., \& Gartner, W. (1990). A profile of new venture success and failure in an emerging industry. Journal of Business Venturing, 5(5), 297-312.

Duckworth, A. L., Kirby, T. A., Tsukayama, E., Bernstein, H., \& Ericsson, K. A. (2011). Deliberate practice spells success: Why grittier competitors triumph at the national spelling bee. Social Psychological and Personality Science, 2(2), 174-181.

Duckworth, A. L., Peterson, C., Matthews, M. D., \& Kelly, D. R. (2007). Grit: Perseverance and passion for long-term goals. Journal of Personality and Social Psychology, 92(6), 1087-1101.

Duckworth, A. L., \& Quinn, P. D. (2009). Development and validation of the short grit scale (grit-s). Journal of Personality Assessment, 91(2), 166-174.

El, 2013. Anxiety of wealth. Economic information. Downloaded at: http://finance.ifeng.com/a/20131012/10840469_0.shtml.

Fee, C. E., Hadlock, C. J., \& Pierce, J. R. (2013). Managers with and without style: Evidence using exogenous variation. Review of Financial Studies, 26, 567-601.

Graham, J., Li, S., \& Qiu, J. P. (2012). Managerial attributes and executive compensation. Review of Financial Studies, 25, 144-186.

Graham, J., and K Narasimhan, (2005). Corporate survival and managerial experiences during the great depression. Working paper, Duke University.

Jain, B. A., \& Kini, O. (1994). The post issue operating performance of IPO firms. Journal of Finance, 49, 1699-1726.

Jo, H., \& Lee, J. (1996). The relationship between an entrepreneur's background and performance in a new venture. Technovation, 16(4), 161-171. 
Lee, D. Y., \& Tsang, E. W. K. (2001). The effects of entrepreneurial personality, background and network activities on venture growth. Journal of Management Studies, 38(4), 583-602.

Maddi, S. R., Erwin, L. M., Carmody, C. L., Villarreal, B. J., White, M., \& Gundersen, K. K. (2013). Relationship of hardiness, grit, and emotional intelligence to internet addiction, excessive consumer spending, and gambling. The Journal of Positive Psychology, 8(2), 128-134.

Malmendier, U., \& Tate, G. (2005). CEO overconfidence and corporate investment. Journal of Finance, 60, 2661-2700

Malmendier, U., Tate, G., \& Yan, J. (2011). Overconfidence and early-life experiences: The effect of managerial traits on corporate financial policies. Journal of Finance, 66, 1687-1733.

Meyer, J. P., \& Allen, N. J. (1991). A three-component conceptualization of organizational commitment. Human Resources Management Review, 1, 61-89.

Meyer, J. P., \& Herscovitch, L. (2001). Commitment in the workplace: Toward a general model. Human Resource Management Review, 11, 299-326.

Mikkelson, W. H., Partch, M. M., \& Shah, K. (1997). Ownership and operating performance of companies that go public. Journal of Financial Economics, 44, 281-307.

Mooradian, T., Matzler, K., Uzelac, B., \& Bauer, F. (2016). Perspiration and inspiration: Grit and innovativeness as antecedents of entrepreneurial success. Journal of Economic Psychology, 56, 232-243.

Rauch, A., \& Frese, M. (2007). Born to be an entrepreneur? Revisiting the personality approach to entrepreneurship. In J. R. Baum, M. Frese, \& R. A. Baron (Eds.), The psychology of entrepreneurship (pp. 44-66). Mahwah: Erlbaum.

Reilly, F. K. (1977). New issues revisited. Financial Management, 6(4), 28-42.

Ritter, J. R. (1991). The long-run performance of initial public offerings. Journal of Finance, 46, 3-27.

Schmitt-Rodermund, E. (2004). Pathways to successful entrepreneurship: Parenting, personality, early entrepreneurial competence, and interests. Journal of Vocational Behavior, 65(3), 498-518.

Schoar, A., and L Zuo, (2017). Shaped by booms and busts: How the economy impacts CEO careers and managerial styles. Review of Financial Studies, 30(5), 1425-1456.

Shane, S. (2004). A general theory of entrepreneurship: The individual-opportunity nexus. Northampton: Edward Elgar.

Shane, S., \& Nicolaou, N. (2015). Creative personality, opportunity recognition and the tendency to start businesses: A study of their genetic predispositions. Journal of Business Venturing, 30(3), 407-419.

Stewart Jr., W. H., Watson, W. E., Carland, J. C., \& Carland, J. W. (1998). A Proclivity for Entrepreneurship: A Comparison of Entrepreneurs, Small Business Owners, and Corporate Managers. Journal of Business Venturing, 14(2), 189-214.

Teoh, H. S., Welch, I., \& Wong, T. J. (1998). Earnings management and the long-run market performance of initial public offerings. Journal of Finance, 53(6), 1935-1974.

Wall Street Journal, (2014). The great Chinese exodus. Reporter: Andrew Browne, August 15. Downloaded at: https://www.wsj. com/articles/the-great-chinese-exodus-1408120906.

Zhao, H., \& Seibert, S. E. (2006). The big five personality dimensions and entrepreneurial status: A meta-analytical review. Journal of Applied Psychology, 91(2), 259-271.

Zhao, H., Seibert, S. E., \& Lumpkin, G. T. (2010). The relationship of personality to entrepreneurial intentions and performance: A meta-analytic review. Journal of Management, 36(2), 381-404.

\section{Submit your manuscript to a SpringerOpen ${ }^{\circ}$ journal and benefit from:}

- Convenient online submission

- Rigorous peer review

- Open access: articles freely available online

- High visibility within the field

- Retaining the copyright to your article

Submit your next manuscript at $\boldsymbol{\nabla}$ springeropen.com 